\title{
Serological markers for hepatitis a among captive and free-living wild mammals in the State of Pará, Brazil
}

\section{Marcadores sorológicos para hepatite A entre mamíferos silvestres cativos e de vida livre do Estado do Pará, Brasil}

\begin{abstract}
Marcella Katheryne Marques Bernal1*; Alex Júnior Souza de Souza²; Heloisa Marceliano Nunes ${ }^{3}$; Andreza Pinheiro Malheiros ${ }^{4}$; André Antônio Corrêa das Chagas"; Sara Letícia dos Santos Andrade ${ }^{5}$; Andréa Lima Silva Figueiredo Amanda Desirée Assunção $\mathrm{Cecim}^{7}$; Washington Luiz Assunção Pereira ${ }^{8}$
\end{abstract}

\section{Highlights}

Hepatovirus found in the Amazonian mammal fauna.

ELISA test for total anti-HAV revealed serological scar in wild mammals.

The origin of an enzootic cycle can be avoided with preventive health actions.

\begin{abstract}
The hepatitis $A$ virus (HAV, Hepatovirus $A$ ) in humans has a relevant impact on public health, especially in geographic regions with poor basic sanitation, such as the Brazilian Amazon. Isolates related to hepatoviruses have been described in non human primates, chiropterans, marsupials, rodents, marmots, shrews, and terrestrial hedgehogs. However, the circulation of these viruses in the Amazonian mammal fauna remains unexplored. This study aimed to evaluate the prevalence of antibodies against this hepatovirus in captive and free-living wild mammals belonging to the orders Didelphimorphia, Primates, Carnivora, and Artiodactyla. Serum samples from 71 animals, from three municipalities in the State of Pará (Belém, Santarém, and CapitãoPoço) were tested for total anti-HAV and anti-HAV IgM through enzyme-linked immunosorbent assay (ELISA). Total anti-HAV antibodies were detected in $29.5 \%$ (21/71) of non-human primates, $8.4 \%$ (6/71) of carnivores,

1 Student of the Doctoral Course of the Pós-Graduate Program Animal Healt and Production in the Amazon, Federal Rural University of the Amazon, UFRA, Belém, PA, Brazil, E-mail: mkbernalfh@gmail.com

2 Prof. Dr., University Paulista, UNIP, São Paulo, SP, Brazil. E-mail: souzajralex@gmail.com

${ }^{3}$ Research Dra, Hepatology Section, Evandro Chagas Institute, IEC, Belém, PA, Brazil. E-mail: heloisanunes@iec.gov.br

${ }^{4}$ Research Tecnologista M.e., Hepatology Section, Evandro Chagas Institute, IEC, Belém, PA, Brazil. E-mail: andrezamalheiros@yahoo.com.br; andrechagas@iec.gov.br

5 Veterinary, Federal Rural University of Amazon, UFRA, Belém, PA, Brazil. E-mail: saralsandrade02@gmail.com

${ }^{6}$ Research Technique, Hepatology Section, IEC, Brazil. E-mail: andrealima@iec.gov.br

7 Student of the Master Course of the Pós-Graduate Program in Virology, IEC, Ananindeua, PA, Brazil. E-mail: amandacecim1@hotmail.com

8 Prof. Dr., Departament Animal Pathology, UFRA, Belém, PA, Brazil. E-mail: wkarton@terra.com.br

* Author for correspondence
\end{abstract}

Received: Mayo 15, 2020 - Approved: Mar. 08, 2021 
and $5.6 \%(4 / 71)$ of didelphos. All tayassuidos $0 \%(0 / 2)$ were seronegative. Anti-HAV IgM antibodies were not detected in any of the samples tested. The highest total anti-HAV seropositivity in the municipalities studied was in Santarém with 54.24\% (12/22), followed by Capitão Poço with 50\% (15/30), and then Belém with $21.05 \%$ (4/19). Among the seropositive animals, animals kept in exposure cages showed 43.9\% (18/41), quarantined animals with $60 \%$ (9/15), and free-living animals with $26.6 \%$ (4/15). The serological results indicated a profile of previous exposure to hepatovirus among these animals. Therefore, additional studies to characterize HAV-related viruses in captive and free living wild animals need to be conducted to better understand the impact of the circulation of this virus on human and animal health.

Key words: Amazon. Viral hepatitis. Hepatovirus A. Mastofauna. Serology.

\section{Resumo}

O vírus da hepatite $A$ (HAV, Hepatovirus A) em seres humanos apresenta relevante impacto na saúde pública, principalmente em regiões geográficas com saneamento básico deficiente, como a Amazônia brasileira. Isolados relacionados a hepatovírus foram descritos em primatas não humanos, quirópteros, marsupiais, roedores, marmotas, musaranhos e ouriços terrestres, entretanto a circulação destes vírus na mastofauna Amazônia ainda permanece desconhecida. O presente estudo objetivou avaliar a prevalência de anticorpos contra esse hepatovírus, em mamíferos silvestres cativos e de vida livre, pertencentes às ordens Didelphimorphia, Primates, Carnivora e Artiodactyla. Amostras de soro de 71 animais, provenientes de três municípios do Estado do Pará (Belém, Santarém e Capitão-Poço) foram testadas para pesquisa de anti-HAV total e anti-HAV IgM por técnica imunoenzimática (ELISA). Anticorpos anti-HAV total foram detectados em 26,75\% (19/71) dos primatas não-humanos, seguido dos felídeos com 11,26\% (8/71) e didelphos com 4,24\% (3/71), todos os tayassuídes (0/2) foram soronegativos. Anticorpos anti-HAV IgM não foram detectados em nenhuma das amostras testadas. A maior prevalência sorológica para o anti-HAV total ocorreu no município de Santarém (54,24\%). E dentre animais soropositivos os mantidos apresentou $43,9 \%$ (18/41) dos espécimes, os de quarentena com $56,25 \%(9 / 16)$ e os de vida livre com $21,43 \%(3 / 14)$. Os resultados sorológicos indicaram perfil de exposição pregressa à hepatovírus entre os animais, portanto estudos adicionais para caracterização de vírus relacionados ao HAV em animais silvestres de cativeiro e vida livre precisam ser desenvolvidos para melhor compreensão do impacto da circulação do agente na saúde humana e animal.

Palavras-chave: Amazônia. Hepatite viral. Hepatovirus A. Mastofauna. Sorologia.

\section{Introduction}

The hepatitis A virus (HAV) is a nonenveloped virus, classified in the family Picornaviridae, species Hepatovirus $A$, and comprises a positive polarity RNA genome and icosahedral symmetry capsid and presents primary hepatocyte tropism and induces hepatitis A in humans (R. S. Koff, 1998).
The main route of HAV contagion is fecal-oral, that is through water or food contaminated with viral particles, which directly relates the epidemiology of the virus to hygiene and basic sanitation conditions (Center for Disease Control and Prevention [CDC], 2009; Paula, 2012). HAV is the main infectious agent that causes hepatitis in humans with approximately 1.5 million clinical cases and 
11,000 deaths registered annually worldwide (Jacobsen \& Wiersma, 2010). This reality can be related both to the country's hygienic sanitary conditions (Paula, 2012; Aggarwal \& Goel, 2015) and the physico-chemical characteristics of the virus that provide it with resistance toward the environment (Hollinger \& Emerson, 2001).

The pathogenesis and molecular epidemiology of HAV is not yet fully understood. In many regions of South America, the distribution of genotypes, endemicity patterns, and potential HAV hosts are unknown (Vaughan et al., 2014). Anthony et al. (2015) suggested that HAV may have zoonotic origins and that strains of this virus coevolved between non-human (PNH) and human primates, which are considered as natural reservoirs of HAV (Hollinger \& Martin, 2013). Isolates of this $\mathrm{PNH}$ virus and humans are classified into six genotypes (identified I-VI) and belong to a single serotype (Vaughan et al., 2014; Drexler et al., 2015).

HAV is classically considered as an agent of exclusive circulation between $\mathrm{PNH}$ and humans (Jacobsen \& Wiersma, 2010; Paula, 2012; X. Wang et al., 2015). However the genus Hepatovirus was recently expanded after the characterization of new HAV-related isolates (International Committee on Taxonomy of Viruses [ICTV], 2018), Hepatovirus B (HVB) was described in Phoca vitulina (Anthony et al., 2015); Hepatovirus C (HCV) in Miniopterus cf. manavi; Hepatovirus D (HDV) in Microtus arvali; Hepatovirus E (HEV) in Lophuromys sikapusi; Hepatovirus F (HFV) in Sigmodon mascotensis; Hepatovirus G (HGV) in Coleura afra; Hepatovirus $H(\mathrm{HHV})$ in Erinaceus europaeus; and Hepatovirus I (HIV) in Sorex araneus (Drexler et al., 2015). New hepatoviruses have also been detected in Himalayan Marmots (Yu et al., 2016), Papio anubis (Bennett et al., 2016), Hipposideros armiger (W. L. Wang et al., 2018), and Didelphis aurita (Carneiro et al., 2018).

In some laboratory species such as guinea pigs (Horney et al., 2001), HAV replication is limited; therefore, the discovery of new Hepatovirus isolates and hosts expands the potential experimental model prospects for studying HAV (Anthony et al., 2015), contributing to the understanding of the evolution of the virus (Drexler et al., 2015).

In the Amazon region, the prevalence of total anti-HAV antibodies is higher than the other regions in the country (Clemens et al., 2000; F. Bensabath \& Leão, 2016), home to approximately $70 \%$ of the diversity in the Brazilian mastofauna (Lewisohn \& Prado, 2002), which are potential wild hosts of infectious agents that may not have been discovered (Yahner, 1992).

Jones et al. (2008) suggested that the majority of emerging human infectious diseases come from wild animals. Therefore, the characterization of infectious agents in domestic and wild animals can provide relevant data on the natural history of human diseases (Anthony et al., 2015).

Few studies have been conducted on anti-HAV antibodies in mammals in the Amazon. Soares, Bensabath, and Travassos Da Rosa (1987) detected anti-HAV antibodies in free-living didelphis and Pereira, Galo, Silva, Soares and Alves (2010) in non-human primates, which should encourage studies to find potential hosts for this hepatotropic virus.

Considering the richness of the mammal fauna, the anthropogenic action, changes in ecological niches, and the 
narrowing of wild animal habitats, it is essential to conduct research on viral hepatitis among animals. The wild can be a natural reservoir of hepatovirus; however, the Brazilian Amazon remains unexplored in this aspect. This study aimed to describe the frequency of serological markers for hepatitis A among captive and free-living wild animals in the State of Pará, Brazil.

\section{Material and Methods}

This research was approved by the Ethics Committee on the Use of Animals (CEUA) of the Federal Rural University of the Amazon (UFRA) under protocol number 034/2014, and the Chico Mendes Institute for Biodiversity Conservation (ICMBio / SISBIO) under number 39285-2.

Study and sampling area

The collection of 71 samples from the blood of wild mammals for analysis was conducted from August 2016 to July 2017, in farms that maintain wild animals in the State of Pará, such as Fundação Museu Paraense Emilio Goeldi (Belém, Pará), Brazilian Agricultural Research Corporation (EMBRAPA / Belém, Pará), Zoo of the Integrated Faculty of Tapajós (Santarém, Pará), Conservationist Conservationist Gavião Real (Capitão Poço, Pará), and the forest islets present on the UFRA campus.

Of the mammals studied, 15 specimens were free-living (Table 1), and 56 were from captivity (Table 2), of which 41 specimens lived in exposure cages and 15 in quarantine enclosures. The animals evaluated belonged to 20 different species, distributed among the four orders Didelphimorphia, Primates, Carnivora, and Artiodactyla; among them, 30 samples were females (Didelphimorphia = 4; Primates $=19$; Carnivora $=7$ ), and 39 were males $($ Didelphimorphia $=11 ;$ Primates $=24 ;$ Carnivora $=4$ ), while two Artiodactylas are newborns and the sex cannot be identified. The samples remained stored in a $-80^{\circ} \mathrm{C}$ freezer until laboratory processing.

\section{Table 1}

Free-living wild mammals from the city of Belém tested for hepatitis A serological markers distributed according to order, family, species, number, and percentage of specimens

\begin{tabular}{ccccc}
\hline Order & Family & Species & N$^{\circ}$ specimens & \% specimens \\
\hline Didelphimorphia & Didelphidae & Philander opossum & 13 & 86,66 \\
(Belém) & & Didelphis marsupialis & 02 & 13,33 \\
Total & & 15 & 100
\end{tabular}




\section{Table 2}

Captive wild mammals from the municipalities of Belém, Capitão Poço, and Santarém tested for hepatitis A serological markers distributed according to order, family, species, number, and percentage of specimens

\begin{tabular}{|c|c|c|c|c|c|c|}
\hline \multirow[b]{2}{*}{ Orden } & \multirow[b]{2}{*}{ Family } & \multirow[b]{2}{*}{ Species } & \multicolumn{3}{|c|}{$\mathrm{N}^{\circ}$ specimens } & \multirow{2}{*}{$\begin{array}{c}\% \\
\text { specimens }\end{array}$} \\
\hline & & & Belém & $\begin{array}{c}\text { Capitão } \\
\text { Poço }\end{array}$ & Santarém & \\
\hline \multirow[t]{12}{*}{ Primates } & Cebidae & Saimiri sciureus & 02 & - & - & 3,6 \\
\hline & & Saquinus niger & - & 02 & - & 3,6 \\
\hline & & Cebus albifrons & - & - & 02 & 3,6 \\
\hline & & Sapajus apella & - & 15 & - & 26,7 \\
\hline & & Callithrix jacchus & - & 01 & - & 1,8 \\
\hline & & Leontopithecus chrysomelas & - & 03 & - & 5,3 \\
\hline & Aotidae & Aoutus azarae & - & - & 01 & 1,8 \\
\hline & & Alouatta belzebul & - & - & 02 & 3,6 \\
\hline & Atelidae & Ateles marginatus & - & - & 01 & 1,8 \\
\hline & & Ateles paniscus & - & - & 09 & 16,0 \\
\hline & & Chiropotes albinasus & - & - & 04 & 7,1 \\
\hline & Pitheciidae & Chiropotes satanas & - & - & 01 & 1,8 \\
\hline \multirow[t]{4}{*}{ Carnívora } & Felidae & Leopardus pardalis & - & 04 & - & 7,1 \\
\hline & & Leopardus wiedii & - & 04 & - & 7,1 \\
\hline & & Puma concolor & - & - & 02 & 3,6 \\
\hline & & Phathera onca & - & 01 & - & 1,8 \\
\hline Artiodactyla & Tayassuidae & Pecari tajacu & 02 & - & - & 3,6 \\
\hline Total & & & 04 & 30 & 22 & 100 \\
\hline
\end{tabular}

Search for total anti-HAV and anti-HAV IgM antibodies

The search for serological markers antitotal HAV and anti-HAV IgM was carried out through enzyme-linked immunosorbent assay (ELISA) using commercial kits Symbiosys ${ }^{\circledR}$ (São Paulo, Brazil) and Bioelisa ${ }^{\circledR}$ (Barcelona, Spain), respectively. The microplate reading was obtained on a spectrophotometer (EL 800, Universal Microplate Reader) with a 620-630 nm reference filter. The cutoff value calculations were established according to the manufacturers' instructions. The cutoff value for the total anti-HAV test with a dilution of 1:1000 was considered positive for samples with an absorbance of $\leq 0.693$, while that of the anti-HAV IgM was considered positive for samples with absorbance values $\geq 0.581$ without dilution.

\section{Statistical analysis}

The detection frequencies were described in absolute values, evaluating the qualitative parameters (origin, room, sex, room, and order), and the Tukey test ( $p>0.05)$. 


\section{Results and Discussion}

In this study, $43.5 \%$ (31/71) of the 71 serological samples studied presented seropositivity for the total anti-HAV test. AntiHAV IgM antibodies were not detected in any animal, which indicates that they did not show an acute course or early convalescence serological marker for hepatitis A (R. D. Koff, 1992), whereas antibodies to HAV are persistent for life (San-nguanmoo et al., 2010), suggesting that the mammals studied were exposed to hepatovirus at some point.

The distribution of seropositivity for total anti-HAV in the municipalities are as follows: Santarém with 54.24\% (12/22), Capitão Poço with 50\% (15/30), and Belém with 21.05\% (4/19). The total anti-HAV results demonstrate the virus circulation in the mastofauna that inhabits these regions. The Brazilian Amazon in Bensabath, Soares and Maia (1986), and Leão, Bichara, Fraiha and Vasconcelos (2013) show a high endemicity for HAV, associated with the socioeconomic standard of the population. Therefore, the hygienic-sanitary conditions and the socio-economic level of the population is extremely important, as the infection occurs via the fecal-oral route (Paula, 2012; Lanford, Walker, \& Lemon, 2019).

Another aspect to be analyzed is the origin of the animals (captives in exposure cages, captives in quarantine, and free-living) and the sorption for total anti-HAV. Of the positive specimens collected, 43.9\% (18/41) were from captive animals in exposure cages, $60 \%(9 / 15)$ from those in quarantine, where majority were from seizures conducted by the Environment Policing Battalion, and 36.6\% (4/15) were from free-living mammals. These results suggest that the mastofauna that was kept captive in the State of Pará could be a reservoir for HAV.
Within this context, the health and food management of these animals must be considered, since the viral particle has physico-chemical characteristics that provide infectious viability in the environment for two to four weeks under favorable environmental conditions (Leão et al., 2013); this hepatovirus is enveloped, which provides it with greater stability in the environment due to the absence of polyprotein chains (Seymor \& Appleton, 2001; Hollinger \& Emerson, 2001). The contamination of food and water can carry this virus (Aggarwal \& Goel, 2015; Lanford et al., 2019), the studies mammals could be infected through food and water contamination, if the origin of the food and water provided to them is unknown.

Another aspect to be analyzed is in the behavioral pattern of these animals as described by Setzer, Gaspar, Sidoni, Bueno and Catão-Dias (2014), who studied the presence of hepatoviruses in captive and free-living $\mathrm{PNH}$ and observed $54.5 \%$ positivity only in animals kept in captivity; such result may be related to the behavior of captive $\mathrm{PNH}$ animals exploring their niche with greater frequency in soil areas than free-living animals that have more arboreal habits. Moreover, in this research, there was a significant difference between the seropositivity of free-living mammals in relation to captive and quarantine mammals, the latter two showing the highest seropositivity $(p=0.053)$ also suggesting that changes in behavior of captive wild animals may provide increased exposure to hepatovirus.

As for the orders studied, the following seropositivity indexes were obtained: Primates with $29.5 \%$ (21/71), followed by Carnivora with $8.4 \%(6 / 71)$, and Didelphimorphia with $5.6 \%$ (4/71). All Artiodactyla (0/2) were seronegative. Table 3 shows the distribution of total anti-HAV according to orders and sex. 
Table 3

Detection frequency of total anti-HAV according to order and sex in captive and free-living wild mammals in the State of Pará, from August 2016 to June 2017

\begin{tabular}{ccccccccc}
\multirow{2}{*}{ Order $(n)$} & \multicolumn{3}{c}{$\begin{array}{c}\text { Total anti-HAV positive } \\
\text { Females }\end{array}$} & \multicolumn{2}{c}{ Males } & \multicolumn{2}{c}{ Total negative anti-HAV } \\
& \multicolumn{2}{c}{ Females } & \multicolumn{2}{c}{ Males } \\
\cline { 2 - 9 } & $\mathrm{N}$ & $\%$ & $\mathrm{~N}$ & $\%$ & $\mathrm{~N}$ & $\%$ & $\mathrm{~N}$ & $\%$ \\
\hline Primates (43) & 9 & 12,6 & 12 & 16,9 & 10 & 14,0 & 10 & 14,0 \\
Carnivora (11) & 4 & 5,6 & 2 & 2,8 & 3 & 4,2 & 3 & 4,2 \\
Didelphimorphia (15) & 2 & 2,8 & 2 & 2,8 & 2 & 2,8 & 2 & 2,8 \\
Artiodactyla (2) & - & - & - & - & - & - & - & - \\
Total (71) & 15 & 21 & 16 & 22,5 & 15 & 21 & 23 & 32,3
\end{tabular}

Source: Samples collected. Specimens of newborn artiodactylas that had difficulties in identifying the sex. Conventional sign used: - numeric data equal to zero, not resulting from rounding.

The results of the present study showed a great diversity of hosts for HAV distributed in four orders, and these could act as reservoirs for the maintenance of the circulation of the virus in nature, similar to some human diseases in endemic areas.

$\mathrm{PNH}$ are animals susceptible to hepatoviruses (San-nguanmoo et al., 2010); these animals and humans are known natural reservoirs for HAV (Hollinger \& Martin, 2013), with records of cross-transmissions between these hosts (Leduc et al., 1983). The seroprevalence of anti-HAV in $\mathrm{PNH}$ remains unclear (Robertson, 2001); therefor, the research records contribute to the knowledge of how this virus has behaved within the populations of wild mammals in the Amazon region.

In this study, 12 species of PNH were seroreagent: Sapajus apella, Cebus albifrons, Alouatta belzebul, Chiropothes albinasus, Saimiri sciureus, Ateles marginatus, and Ateles panicus. In previous studies, there are records of some species of the $\mathrm{PNH}$ families which showed seropositivity for total anti-HAV, such as Aotus trivirgatus (Lemon, Leduc, Binn, Escajadillo, \& Ishak, 1982) and Cebus spp. (Eichberg \& Kalter, 1980), and in southeastern Brazil, the Cebus spp. and Sapajus spp. (Setzer et al., 2014), and Sapajus nigritus and Alouatta caraya (Svoboda et al., 2016). These citations do not refer to the exact age of the animals where all were asymptomatic and data that corroborate those from the present study. There were no clinical signs observed and these were rescue animals and their age range was unknown. San-nguanmoo et al. (2010) reported that young animals do not show clinical signs but have the ability to eliminate virions and contaminate the environment and other animals.

Other asymptomatic captive animals that were seroreagent are in the order Carnivore of the species Leopardus pardalis and L. wiedii; there are no records of serological studies for total anti-HAV in these neotropic felids. These carnivores that presented this serological scar may be a new group to be evaluated, 
emphasizing susceptibility to hepatoviruses. The hygienic sanitary management of farms may favor enzootic cycles within these living environments, if the origin of the infection is unknown (Robertson, 2001; Nath, Chakraborty, Sarma, Rahman, \& Boro, 2013).

The free-living specimens of the order Didelphimorphia of the species Philander opossum captured in forest fragments in the city of Belém were seroreagent for total anti$\mathrm{HAV}$; these mammals have synanthropic habits and are able to share environment and food with human beings (Reis, Peracchi, Fregonezi, \& Rossaneis, 2010), and this interspecific approach may favor the maintenance of the circulation of pathogens, since didelphos are abletovectorandhostvariousinfectiousagents (Leão et al., 2013). These data corroborate the findings of Soares et al. (1987) and Pereira et al. (2010) who described sorption of total antiHAV in Amazonian rodents, pointing to the circulation of hepatoviruses.

These data demonstrate that there is a possibility of maintaining the circulation of hepatoviruses in wild mammals in the Amazon, in addition to the possible sources of contamination, health management, and the proximity of the interspecific human-fauna relationship, to be reviewed, in order to propose preventive measures to avoid the emergence of a possible anthropozoonotic cycle in the Amazonian mastofauna. Configuring new epidemiological data on the sanitary and socioeconomic quality of the population, some efforts on liver agents are being conducted in the mastofauna (Pereira et al., 2010), but there is still a vast field to cover in the epidemiological understanding of pathogens that affect the Amazonian mammalian fauna.

\section{Conclusions}

From the results obtained, it was concluded that the detection of antibodies against total anti-HAV in free-living and captive mammals proves the environmental circulation of this agent in the State of Pará. Considering that the hepatovirus is transmitted orally, the risk of infection in the human population cannot be ruled out. This study describes the first serological detection of total anti-HAV in mammals in the Amazon region.

Further studies are needed to elucidate the hepatoviruses that circulate among wild Amazonian mammals and the role of these animals in the epidemiological chain of these agents.

\section{Thanks}

We thank the Evandro Chagas Institute - Belém / PA, section of hepatology, for the laboratory support provided throughout the research.

\section{References}

Aggarwal, R., \& Goel, A. (2015). Hepatitis $A$ : epidemiology in resource-poor countries. Current Opinion Infection Diseases, 28(5), 488-496. doi: 10.1097/ QC0.0000000000000188

Anthony, S. J., Leger, J. A. S. T., Liang, E., Hicks, A. L., Sanchez-Leon, M. D., Jain, K.,... Lipkin, W. I. (2015). Discovery of a novel hepatovirus (Phopivirus of Seals) related to human Hepatitis A virus. MBio, 6(4), 1-10. doi: 10.1128/mBio.01180-15 
Bennett, A. J., Sibley, S. D., Lauck, M., Weny, G., Hyeroba, D., Tumukunde, A.,... Goldberg, T. L. (2016). Natturally circulating Hepatitis A Virus in Olive. Emerg Infection Disease, 22(7), 1308-1310. doi: 10.3201/ eid2207.151837

Bensabath, F., \& Leão, R. N. Q. (2016). Epidemiologia na Amazônia brasileira. In R. Focaccia (Ed.), Tratado das Hepatites Virais (pp. 11-26) São Paulo: Atheneu.

Bensabath, G., Soares, M. C. P. \& Maia, M. M. S. (1986). Hepatite por vírus. (p. 483-529) In Instituto Evandro Chagas: 50 anos de contribuição às Ciências Biológicas e à Medicina Tropical. Brasil, Belém: Fundação Serviços de Saúde Pública.

Carneiro, I. O., Sander, A. L., Silva, N., MoreiraSoto, A., Normann, A., Flehmig, B.,... Drexler, J. F. (2018). A novel marsupial hepatites A vírus corroborates complex evolutionary patterns shaping the genus Hepatovirus. Journal Virology, 92(13), 1-37. doi: 10.1128/JVI.00082-18

Center for Disease Control and Prevention (2009). Epidemiologic notes and reports hepatitis $A$ among drug abusers. United States: MMWR Surveill.

Clemens, S. A. C., Fonseca, J. C., Azevedo, T., Calvalcanti, A., Silveira, T. R., Castilho, M. C., \& Clemens, R. (2000). Soroprevalência para hepatite $A$ e hepatite $B$ em quatro centros no Brasil. Revista da Sociedade Brasileira de Medicina Tropical, 33(1), 1-10. doi: 10.1590/S0037-86822000000100001

Drexler, J. F., Corman, V. M., Lukashev, A. N., Brand, J. M. A., Gmyl, A. P., Brunink, S.,... Consortium, H. E. (2015). Evolutionary origins of hepatites Avirus in small mammals. PNAS, 112(49), 1-6. doi: 10.10 73/pnas.1516992112

Eichberg, J. W., \& Kalter, S. S. (1980). Hepatitis $A$ and $B$ : serologic survey of human and nonhuman primate sera. Laboratory Animal Science, 30(3), 541-543. Retrived from https://europepmc.org/article/med/ 6253744

Hollinger, F. B., \& Emerson, S. U. (2001). Hepatitis A virus. In D. M. Knipe, \& P. M. Howley (Eds.), Fields virology (pp. 799-840). New York: Lippincott Williams \& Wilkins.

Hollinger, F. B., \& Martin, A. (2013). Hepatitis a virus. In W. Kluwer (Ed.), Field's virology (pp. 550-581). Philadelphia: Lippincott Williams \& Wilkins.

Horney, B., Kammerer, R., Moubayed, P., Frings, W., Gauss-muller, V., \& Dotzauer, A. (2001). Experimental hepatitis A virus infections in Guinea Pigs. Journal of Medical Virology, 64(4), 402-409. doi: 10.1002/jmv.1065

International Committee on Taxonomy of Viruses (2018). Taxonomy of viruses. Retrieved from https://talk. ictvonline.org/

Jacobsen, K. H., \& Wiersma, S. T. (2010). Hepatitis A virus seroprevalence by age and world region, 1990 and 2005. Vaccine, 28(41), 6653-6657. doi: 10.1016/j.vaccine. 2010.08.037

Jones, K. E., Patel, N. G., Levy, M. A., Storeygard, A., Balk, D., Gittleman, J. L., \& Daszak, P. (2008). Global trends in emerging infectious diseases. Nature, 451(21), 990993. doi: $10.1038 /$ nature06536

Koff, R. D. (1992). Clinical manifestations and diagnosis of hepatitis A vírus infection. Vaccine, 10(1), 15-17. doi: 10.1016/0264410X(92)90533-P 
Koff, R. S. (1998). Hepatitis A. Lancet, 351(1), 1643-1649. doi: 10.1016/S0140-6736(98) 01304-X

Lanford, R.E., Walker, C. M., \&Lemon, S. M. (2019). Nonhuman primate models of Hepatitis $A$ virus and Hepatitis E virus infections. Cold Spring Harb Perspect Medicine, 9(2), 1-29. doi: 10.1101/cshperspect. a031815 .

Leão, R. N. Q., Bichara, C. N. C., Fraiha, N., Neto, \& Vasconcelos, P. F. C. (2013). Medicina Tropical e infectologia na Amazônia (pp. 685-740). Brasil: Samauma.

Leduc, J. W., Lemon, S. M., Keenan, C. M., Graham, R. R., Marchwicki, R. H., \& Binn, L. H. (1983). Experimental infection of the new world owl monkey (Aotus trivirgatus) with hepatitis A virus. Infection and Immunity, 40(2), 766-772. doi: 10.1128/IAI.40.2.766772.1983

Lemon, S. M., Leduc, J. W., Binn, L. N., Escajadillo, A., \& Ishak, K. G. (1982). Transmission of hepatitis $A$ vírus among recently captured Panamian owl monkeys. Journal of Medical Virology, 10, 25-36. doi: 10.1002/ jmv.1890100105

Lewisohn, T. M., \& Prado, P. I. (2002). Biodiversity of Brazil: a synthesis of the current state of knowledge. São Paulo: Contexto Acadêmica.

Nath, B. G., Chakraborty, A., Sarma, D. K., Rahman, T., \& Boro, P. K. (2013). Seroprevalence of Hepatitis A virus infection in non-human primates in Assam, Indian. Journal of Threatened, 5(12), 47224724. doi: 10.11609/JoTT.o3121.4722-4

Paula, V. S. de. (2012). Laboratory diagnosis of hepatitis A. Future Virology, 7(5), 461-472. doi: 10.2217/ fvl.1235
Pereira, W. L. A., Galo, K. R., Silva, K. S. M. D., Soares, M. D. C. P., \& Alves, M. M. (2010). Viral hepatitis, helminthiasis and protozoan disease in neotropical primates reaised in captivity: potentially zoonotic affections with fecal-oral transmission. Revista Pan Amazônica Saúde, 1(3), 57-60. doi: 10.51 23/S2176-62232010000300008

Reis, N. R., Peracchi, A. L., Fregonezi, M. N., \& Rossaneis, B. K. (2010). Mamíferos do Brasil: guia de identificação. São Paulo: Technical Books.

Robertson, B. H. (2001). Viral hepatitis and primates: historical and molecular analysis of human and nonhuman primate hepatitis A, B and GB-related viruses. Journal of Viral Hepatitis, 8(4), 233-242. doi: 10.1046/j.1365-2893.2001.00295.x

San-nguanmoo, P., Thawornsuk, N., Rianthavorn, P., Sommanustweechai, A., Ratanakorn, P., \& Poovorawan, Y. (2010). High prevalence of antibodies against hepatitis A virus among captive nonhuman primates. Primates, 51(2), 167-170. doi: 10.1007/s10329-009-0172-z

Setzer, A. P., Gaspar, A. M. C., Sidoni, M., Bueno, M. G., \& Catão-Dias, J. L. (2014). Serosurvey for hetatitis $A$ in neotropical primates in southeast Brazil. Journal Medical Primatology, 43(3), 202-205. doi: 10.1111/jmp.12106.

Seymor, I. J., Appletton, H. (2001). Foodborne viruses and fresh produce. Journal of Applied Microbiology, 91(5), 759-773. doi: 10.1111/jmp.12106

Soares, M. C. P., Bensabath, G., \& Travassos Da Rosa, A. P. A. (1987). Presença de anticorpos para vírus da hepatite $A$ em Didelphis marsupialis (Vertebrata, 
Marsupialia) da Amazônia. Revista do Instituto de Medicina Tropical, 29(2), 110-111. doi: 10.1590/S003646651987000200008

Svoboda, W. K., Soares, M. C. P., Alves, M. M., Rocha, T. C., Gomes, E. C., Menonci, F.,... Navarro, I. T. (2016). Serological detection of hepatitis A virus in freeranging neotropical primates (Sapajus spp., Aluatta caraya) from the Paraná river basin, Brasil. Revista do Instistituto de Medicina Tropical, 58(9), 1-6. doi: 10.1590/ S1678-994658009

Vaughan, G., Rossi, L. M. G., Forbi, J. C., Paula, V. S. de, Purdy, M. A., Xia, G., \& Khudyakov, Y. E. (2014). Hepatitis A virus: host interactions, molecular epidemiology and evolution. Infection, Genetics and Evolution, 21(4), 227-243. doi: 10.1016/j. meegid.2013.10.023
Wang, W. L., Li, B., Zhang, W., Zhu, Y., Shi, Z. L., \& Yang, X. L. (2018). Genomic characterization of novel hepatovirus from great roundleaf bats in China. Virologica Sinica, 33(1), 108-110. doi: 10.1007/s 12250-018-0013-6

Wang, X., Ren, J., Gao, Q., Hu, Z., Sun, Y., Li, X.,... Fry, E. E. (2015). Hepatitis A virus and the origins of picornaviruses. Nature, 517(1), 85-88. doi: 10.1038/nature13806

Yahner, R. H. (1992). Dynamics of small mammal community in a fragment forest. American Midland Naturalist, 127(2), 381-391. doi: $10.2307 / 2426545$

Yu, J., Li, L., Zhang, C., Lu, S., Ao, Y., Gao, H.,... Duan, Z. J. (2016). A novel hepatovirus identified in wild woodchuck Marmota himalayana. Scientific reports. Nature, 6(1), 1-11. doi: 10.1038/srep22361 
